\title{
The effect of cadmium contained in fertilizers on the cadmium content of vegetables
}

\author{
AntTI JAAKKoLA \\ Agricultural Research Centre, Department of Agricultural Chemistry and Physics, \\ 01300 Vantaa 30
}

Johan Korkman and Tuomo Juvankoski
Kemira Oy, Malminkatu 30,00100 Helsinki 10

\begin{abstract}
The aim of the study was to find out to what extent the cadmium contained in fertilizer influences the cadmium content of vegetables. For this purpose, highly cadmium-bearing batches of fertilizer were prepared from selected quantities of raw material with an exceptionally high cadmium content. To one such batch of fertilizer, an extra amount of cadmium was added at the mixing stage.

In a two-year field experiment carried out in soil consisting of clayey fine sand and begun in $1977,1000 \mathrm{~kg} / \mathrm{ha}$ of NPK fertilizer with a cadmium content of either 57 or $81 \mathrm{mg} / \mathrm{kg}$ brought about a clear increase in the cadmium content of radish tops. The cadmium content of radish roots, spinach and lettuce appeared likewise to rise, but the differences registered were not, owing to the unevenness of the field, significant. The cadmium content of the dry matter of rye grass was lower than that of the other experimental plants, and it appeared to rise less with an increase in the cadmium content of the fertilizer.

Owing to the wide range of variation, the cadmium uptake of the experimental plants could not be determined reliably, The spinach, however, appeared to have taken up the largest amount of cadmium, and the rye grass the least amount. The increase in the cadmium content of the spinach harvested in 1978 corresponded to $1.5 \%$ 。 of the cadmium introduced into the ground during the two-year period through application of the fertilizer with the highest content of the metallic element.
\end{abstract}

\section{Introduction}

Cadmium is a heavy metal, even minute amounts of which in food eaten by human beings are a health hazard. The dangerous nature of cadmium is based expressly on its accumulation in certain organs, notably the kidneys and the liver, and its very slow elimination by the system. Fertilizers are one possible source of cadmium, for the metallic element is known to be present in certain raw materials of fertilizer phosphorus.

Part of the cadmium received by human beings is derived from animal products. Liver and kidneys are significant sources of the element, as cadmium 
contained in fodder accumulates in these organs. However, the direct role of plants is probably more important. Although the cadmium content of grains is rather low, cereal products are a noteworthy source of cadmium to people in view of the large amounts consumed. The effect of fertilization on the cadmium content of wheat grains has also been investigated in Finland (JAAKKоLA 1977). The cadmium content of many other plants, especially certain vegetables, increases much more readily than that of cereal grains (LöNsJö 1975). The purpose of the present study was to ascertain the significance of the cadmium contained in fertilizer in the cultivation of radish, spinach and lettuce. Rye grass was used as a fourth experimental plant to make comparisons.

\section{Material and methods}

A field experiment was carried out in connection with the study in the years 1977 and 1978 at he Kotkaniemi experimental farm in southern Finland. The soil of the ploughed layer in the experimental field consisted of clayey fine sand, which under certain conditions forms to some extent a crust. The $\mathrm{pH}$ measured from the water suspension of the samples taken in the autumn of 1977 from the ploughed layer and the nutrient contents extractable in acid ammonium acetate were as follows:

$\begin{array}{crr}\text { average } & \mathrm{pH} & 6.15 \\ \mathrm{Ca} & 1790 \mathrm{mg} / 1 \\ \mathrm{~K} & 390 \\ \mathrm{Mg} & 67 \\ \mathrm{P} & 49.0\end{array}$

$\begin{array}{cr}\text { range } & 5.15-6.80 \\ \quad & 950-2700 \\ & 310-500 \\ & 32-100 \\ & 23.5-96\end{array}$

With respect to its chemical properties, the field was not especially even. Worthy of note, furthermore, is the rather high content of soluble phosphorus in the soil.

The fertilizers used in the treatments were the following:

1. NPK fertilizer (15\% N, $8.7 \% \mathrm{P}, 12.5 \% \mathrm{~K})$, with Kola apatite as phosphorus raw material; $1.5 \mathrm{mg} / \mathrm{kg} \mathrm{Cd}$ in fertilizer.

2. NPK fertilizer, with Kola apatite as phosphorus raw material; sulphuric acid used in preparation cadmium-bearing; $30 \mathrm{mg} / \mathrm{kg} \mathrm{Cd}$ in fertilizer.

3. NPK fertilizer, with Taiba's rock phosphate as phosphorus raw material; fertilizer contains $57 \mathrm{mg} / \mathrm{kg} \mathrm{Cd}$.

4. NPK fertilizer, with Taiba's rock phosphate as phosphorus raw material; cadmium added separately, fertilizer containing a total of $81 \mathrm{mg} / \mathrm{kg}$ Cd.

No. 1 fertilizer was obtained from the regular market, while fertilizers $2-4$ were prepared specially for experimental purposes by Kemira's experimental fertilizer plant. The same batches of fertilizer were used in the spring wheat experiment described by JAAKKola (1977).

The experimental field was divided into 16 main plots, each one measuring $4 \times 4 \mathrm{~m}$. The treatments were set up in the main plots in the form of a Latin square. The fertilizer was broadcast over each main plot by hand and then mixed in the soil by harrowing. The amount of fertilizer used was $1000 \mathrm{~kg}$ per ha both years (1977 and 1978). Each plot was fertilized with the same mixture both years. 
Each main plot was divided after fertilization into four subplots, one for each of the four experimental plants. The plants were:

\section{Radish. 2. Spinach. 3. Lettuce. 4. Italian rye grass}

Three rows of each plant were sown in one-metre wide plots - in the same plots both years. The days on which the sowing was done were May 23, 1977, and May 17, 1978.

At harvesting plant samples were taken from each plot for the determination of the cadmium content. The determinations were made by the flameless atomic absorption method from the acid extract of ashes ignited at $450^{\circ} \mathrm{C}$ (apparatus: Varian Techtron). In 1978, 1/3 sq.m. of each plot was harvested. The radish tops and roots were harvested separately. The rye grass was mown three times each year.

\section{Results and discussion}

The cadmium contents of the dry matter of the plants are set forth in Table 1. Although the cadmium contents of the dry matter of the crops treated with fertilizer containing no cadmium were found to be high compared with, for example, the contents of spring wheat grains (JAAKKOLA 1977), they were evidently not exceptional. The cadmium content of, for instance, the spinach was distinctly lower than that of spinach reported by LARSEN (1975) to have been grown in uncontaminated soil. The cadmium content of the rye grass was lower than that of the other experimental plants. The contents observed in the 1 . and 2 . cuttings of 1977 are apparently rather high, although not much above the figures published by LARSEN (1975).

An increase in the cadmium content of the fertilizer appeared in many cases to lead to an increase in the cadmium content of the plants. The variation was so great, however, as to make it impossible to decide for certain whether the effect was real or whether the differences were accidental. The cadmium content of the tops of the radishes grown in 1977 increased significantly when the fertilizer contained 57 or $81 \mathrm{mg} / \mathrm{kg} \mathrm{Cd}$. The content of the second cutting of rye grass grown in 1978 increased significantly even after application of fertilizer containing only $30 \mathrm{mg} / \mathrm{kg} \mathrm{Cd}$. The change in the cadmium content of the rye grass was, however, slight.

Although the same plots were given highly cadmium-bearing fertilizer two years in succession, the cadmium contents of the second year's crop did not increase any more distinctly than those of the first cear's crop. In this two-year experiment, therefore, the repeated application of cadmium-bearing fertilizer could not be observed to have caused any augmentation in the effect. With the application of the NPK fertilizer containing the most cadmium, $160 \mathrm{~g}$ of cadmium were introduced into the ground during the two-year period - an amount that must be considered large.

On the basis of the yields weighed in 1978, also the cadmium uptake by the crops was calculated (Table 2). The average yields of the different treatments varied considerably, mainly on account of the unevenness of the field 
Table 1. Dependence of $\mathrm{Cd}$ content of plants on $\mathrm{Cd}$ content of fertilizer $(1000 \mathrm{~kg} / \mathrm{ha} / \mathrm{a})$.

\begin{tabular}{|c|c|c|c|c|c|c|c|}
\hline & \multicolumn{2}{|c|}{ Date of } & \multicolumn{5}{|c|}{ Cadmium content, $\mathrm{mg} / \mathrm{kg}$ in plant D.M. } \\
\hline & \multirow[t]{2}{*}{ sowing } & \multirow[t]{2}{*}{ harvest } & \multicolumn{4}{|c|}{$\mathrm{Cd}$ in fertilizer, $\mathrm{mg} / \mathrm{kg}$} & \multirow{2}{*}{ LSD $5 \%$} \\
\hline & & & 1 & 30 & 57 & 81 & \\
\hline Radish 1977, & 23. V & 28. VI & & & & & \\
\hline tops & & & 0.32 & 0.44 & 0.45 & 0.52 & 0.13 \\
\hline roots & & & 0.29 & 0.34 & 0.32 & 0.31 & 0.10 \\
\hline Radish 1978, & 17. V & 14. VI & & & & & \\
\hline tops & & & 0.63 & 0.67 & 0.68 & 0.75 & 0.18 \\
\hline roots & & & 0.28 & 0.32 & 0.31 & 0.32 & 0.09 \\
\hline Spinach 1977, & 23. V & 7.V II & 0.7 & 0.7 & 0.8 & 0.7 & 0.4 \\
\hline Spinach 1978. & 17. V & 27. VI & 0.9 & 1.0 & 1.1 & 1.2 & 0.8 \\
\hline Lettuce 1977, & 23. V & 19. VII & 0.35 & 0.31 & 0.31 & 0.31 & 0.14 \\
\hline Lettuce 1978, & 17. V & 27. VI & 0.45 & 0.45 & 0.48 & 0.53 & 0.11 \\
\hline Rye grass 1977 , & 23. V & & & & & & \\
\hline 1. cuttting & & 19. VII & 0.17 & 0.17 & 0.17 & 0.18 & 0.05 \\
\hline $2 . \quad$ & & 9. VIII & 0.12 & 0.14 & 0.12 & 0.14 & 0.05 \\
\hline 3. & & 5. IX & 0.06 & 0.05 & 0.06 & 0.06 & 0.02 \\
\hline Rye grass 1978 , & 17. V & & & & & & \\
\hline 1. cutting & & 27. VI & 0.05 & 0.05 & 0.06 & 0.05 & 0.02 \\
\hline $2 . \quad$ & & 5. VII & 0.11 & 0.13 & 0.13 & 0.14 & 0.02 \\
\hline $3 . \quad$ & & 2. VIII & 0.06 & 0.06 & 0.06 & 0.07 & 0.02 \\
\hline
\end{tabular}

Table 2. Yields (kg/ha D.M.) and dependence of their cadmium uptake (mg/ha) on cadmium content of fertilizer. Year 1978.

\begin{tabular}{|c|c|c|c|c|c|}
\hline & \multicolumn{4}{|c|}{$\mathrm{Cd}$ in fertilizer, $\mathrm{mg} / \mathrm{kg}$} & \multirow{2}{*}{ LSD $5 \%$} \\
\hline & 1 & 30 & 57 & 81 & \\
\hline \multicolumn{6}{|l|}{ Radish } \\
\hline tops, $\mathrm{kg} / \mathrm{ha}$ & 310 & 450 & 280 & 350 & 160 \\
\hline roots, $\mathrm{kg} / \mathrm{ha} . . . . . . . .$. & 290 & 390 & 310 & 350 & 90 \\
\hline Cd uptake, mg/ha & 280 & 430 & 290 & 370 & 180 \\
\hline \multicolumn{6}{|l|}{ Spinach } \\
\hline yield, kg/ha ......... & 410 & 470 & 490 & 460 & 90 \\
\hline Cd uptake, mg/ha & 340 & 440 & 560 & 580 & 440 \\
\hline \multicolumn{6}{|l|}{ Lettuce } \\
\hline yield, $\mathrm{kg} / \mathrm{ha}$.......... & 410 & 640 & 770 & 760 & 560 \\
\hline Cd uptake, mg/ha & 180 & 280 & 360 & 390 & 240 \\
\hline \multicolumn{6}{|l|}{ Rye grass } \\
\hline 1. cutting, $\mathrm{kg} / \mathrm{ha} \ldots$ & 560 & 630 & 550 & 590 & 80 \\
\hline 2.,$\ldots$ & 480 & 490 & 510 & 510 & 140 \\
\hline 3. $, \quad, \ldots$ & 2150 & 2480 & 2070 & 2160 & 730 \\
\hline Cd uptake, mg/ha & 220 & 240 & 220 & 250 & 110 \\
\hline
\end{tabular}


and the small size of the plots. Since the random variation of the cadmium contents was large, too, it is evident that the amounts of cadmium measured varied over quite a broad range. No significant differences could be observed, although the apparent differences were clear. In the yields of all four plants grown, the amounts of accumulated cadmium appeared to have increased with a rise in the cadmium contents of the fertilizer. The largest apparent increase in the cadmium uptake, $240 \mathrm{mg} / \mathrm{ha}$, in the case of the spinach, corresponded to $1.5 \%$ of the cadmium introduced into the soil along with the fertilizer, during two years.

\title{
REFERENCES
}

JАаккоLA, A. 1977. Effect of fertilizers, lime and cadmium added to soil on the cadmium content of spring wheat. J. Scient. Agric. Soc. Finl. 49: 406-414.

LARSEN, S. D. 1975. Planternes optagelse af tungmetaller efter gødskning med tungmetalholdigt spildevandsslam. NJF. Seminar om tungmetaller, sirkulasjon $\mathrm{i}$ jordbruket. Ås. p. $145-156$.

LöNSJö, H. 1975. Studier med hjälp av isotopteknik av grödors upptagning av kadmium från rötslam tillfört till olika jordtyper. NJF. Seminar om tungmetaller, sirkulasjon i jordbruket. Ås. p. 101-113.

Ms received March 28, 1979

\section{SELOSTUS}

\section{Lannoitteiden sisältämän kadmiumin vaikutus vihannesten kadmiumpitoisuuteen}

\author{
Antti JaAkKola \\ Maatalouden tutkimuskeskus, Maanviljelyskemian ja -fysiikan laitos, 01300 Vantaa 30 \\ Johan Korkman ja Túmo JuvanKoski \\ Kemira Oy, Malminkatu 30, 00100 Helsinki 10
}

Tutkimuksessa pyrittiin selvittämään, missä määrin lannoitteen sisältämä kadmium vaikuttaa vihannesten kadmiumpitoisuuteen. Tätä varten valmistettiin erittäin kadmiumpitoisia lannoite-eriä valikoiduista, poikkeuksellisen kadmiumpitoisista raaka-aine-eristä. Yhteen tällaiseen lannoite-erään lisättiin kadmiumia vielä sekoitusvaiheessa.

Vuonna 1977 aloitetussa kaksivuotisessa karkealla hietamaalla suoritetussa kenttäkokeessa $1000 \mathrm{~kg} /$ ha normaalia Y-lannosta, jonka kadmiumpitoisuus oli 57 tai $81 \mathrm{mg} / \mathrm{kg}$, kohotti selvästi retiisin naattien kadmiumpitoisuutta. Myös retiisin juurten, pinaatin ja salaatin sekä jossakin määrin myös raiheinän kadmiumpitoisuus näytti kohoavan, mutta ero ei ollut kentän epätasaisuuden takia merkitsevä. Raiheinän kuiva-aineen kadmiumpitoisuus oli alempi kuin muiden koekasvien ja se nousi vähemmän lannoitteen kadmiumpitoisuuden lisääntyessä.

Koekasvien kadmiumin oton määrää ei voitu suuren vaihtelun johdosta selvittää luotettavasti. Pinaatti näytti kuitenkin ottaneen kadmiumia eniten ja raiheinä vähiten. Vuonna 1978 korjatun pinaatin sisältämän kadmiummäärän nousu vastasi $1,5 \%$ maahan kahden vuoden aikana kadmiumpitoisimmasta lannoitteesta joutuneesta kadmiumista. 